\title{
STAT6 wt Allele
}

National Cancer Institute

\section{Source}

National Cancer Institute. STAT6 wt Allele. NCI Thesaurus. Code C52157.

Human STAT 6 wild-type allele is located in the vicinity of $12 q 13$ and is approximately 16 $\mathrm{kb}$ in length. This allele, which encodes signal transducer and activator of transcription 6 protein, plays a role in apoptosis regulation, $\mathrm{T}$ helper cell differentiation, immunog lobulin class determination and the cellular response to interleukin-4. 